\title{
A Cross-Country Analysis of Monetary Policy Effects on Prices*
}

\author{
Bruno ĆORIĆ—corresponding author (bcoric@efst.hr) \\ Lena MALEŠEVIĆ PEROVIĆ \\ Vladimir ŠIMIĆ \\ all authors: Faculty of Economics, University of Split
}

\begin{abstract}
What determines the size of monetary policy effects on prices? This is one of the crucial questions for the efficient conduct of monetary policy. Therefore, this study investigates this issue by exploring variations in the responsiveness of prices to a monetary policy shock across 46 developed and developing countries. We first use a structural vector autoregression model to estimate monetary policy effects for each country separately. The estimated effects are thereafter treated as the dependent variable in a cross-country regression. The results suggest that the size of the short-run effect of a monetary policy shock on prices is significantly larger in countries with higher trade openness, a more flexible exchange rate, and a larger and more developed banking sector, while the effect is smaller in countries with the English legal origin.
\end{abstract}

\section{Introduction}

The efficient implementation of monetary policy measures requires policymakers to know the approximate size of the impact of these measures on the economy. Therefore, the question of what determines the size of monetary policy effects on prices is one of the crucial questions for policymakers. Better understanding of monetary transmission determinants may be of particular importance today, when a number of economists and policymakers express their "fears" that the growing internationalization of economic activity undermines the ability of national central banks to affect prices.

A number of empirical studies address this issue by exploring the crosscountry and cross-regional differences in the effects of monetary policy shocks (see, for example, Carlino and DeFina, 1998, 1999; Cecchetti, 1999; Mihov, 2001; Elbourne and Haan, 2006; Owyang and Wall, 2009; Aysun et al., 2013; Matějů, 2013; Ćorić et al., 2014). This literature, however, primarily concentrates on output responses to a monetary policy shock and focuses on the impact of the financial structure and the share of the manufacturing sector on monetary policy effects, thus investigating the importance of the interest rate and credit channels of monetary policy. Crosscountry differences in the effects of a monetary policy shock on prices remain relatively under-investigated, as does the possible impact of economic openness on the responsiveness of prices to a domestic monetary policy shock.

In particular, cross-country differences in the effects of monetary policy on prices are investigated in Cecchetti (1999), Elbourne and Haan (2006) and Matějů

\footnotetext{
* The authors would like to thank Nick Adnett, Edward Christie, Mario Holzner, Evan Kraft, Ivo Krznar and two anonymous referees for their helpful comments and suggestions. This research was supported by a grant from the CERGE-EI Foundation under a program of the Global Development Network. All opinions expressed are those of the authors and have not been endorsed by CERGE-EI or the GDN.
} 
(2013). Cecchetti (1999) analyzes relationships between countries' financial and legal systems and price responses to a monetary policy shock in ten old EU countries and the US. Similarly, Elbourne and Haan (2006) concentrate on the relationship between the financial structure and price responses to a monetary policy shock, but focusing on the ten new EU countries. The possible effect of trade openness on price responses to a monetary policy shock is addressed in the Matějü's (2013) recent research on monetary policy transmission in 33 OECD and EU countries. The relationship between openness and the effects of monetary policy on prices is also analyzed in meta-analysis of the literature on monetary transmission carried out by Rusnak et al. (2013). Specifically, Rusnak et al. (2013) collected a large number of estimates of price responses to a monetary policy shock from the existing empirical studies. A metaregression analysis was then used to explore the sources of differences in the effects of monetary policy on prices reported in the literature. However, with respect to the possible effect of economic openness on monetary policy transmission, the authors focus on trade openness only.

Why should economic openness influence the responsiveness of prices to a domestic monetary policy shock? The potential relationship between the growing internationalization of national economies and the responsiveness of prices to a monetary policy shock is admittedly very complex. It ranges from traditional considerations formulated by the well-known exchange rate channel of monetary policy and the Mundell-Fleming model of macroeconomic policy in an open economy to the more recent considerations discussed by, among others, Rogoff (2003, 2007); BIS (2006); Bernanke (2007); Mishkin (2009), Woodford (2010), Kamin (2010) and Cwik et al.(2011).

The possible effects of international capital mobility on monetary policy transmission caused by the growing internationalization of financial markets around the world over the recent decades have stimulated a lively debate (see, for example, BIS, 2006, chapter IV; Yellen, 2006; Bernanke, 2007; Rogoff, 2007; Gudmundsson, 2008; and Kamin, 2010). As a result, the two main reasons were put forth as to why international capital mobility can undermine the ability of central banks to affect prices. First, the mobility of capital across borders can make the short-term nominal interest rate more sensitive to the supply of "global liquidity" than to the supply of liquidity by the national central bank, thus reducing the power of the central bank to influence the short-term nominal interest rate. Second, this mobility of capital can make the long-term real interest rates more sensitive to the balance between global savings and investment than to this balance at the country level. This may, consequently, diminish the ability of the central bank to affect the long-term real interest rate. However, Woodford (2010) shows that within the standard new Keynesian open-economy DSGE model financial openness does not reduce the short-run effects of monetary policy on prices. Meier (2013) extended Woodford's (2010) model with a richer financial structure and found that financial openness can even increase the effects of monetary policy.

Under the traditional monetarist analysis, monetary policy affects not just one but many assets prices and in an open-economy framework the exchange rate becomes one of the relative prices in the monetarist transmission process (see, for example, Meltzer, 1995, and Mishkin, 1995). The so-called exchange rate channel of monetary policy suggests that a change in the short-term interest rate induced by monetary 
policy measures influences aggregate demand through its effect on the exchange rate and international trade. In addition to this indirect effect on prices through the effect on aggregate demand, prices can also be directly affected by the induced change in the exchange rate. This occurs because the change in the exchange rate directly affects the prices of intermediate and final imported goods and results in a change of the overall price level in the economy. One of the implications of this channel is that the short-run effect of a monetary policy shock on prices is expected to be larger the more open the economy is to international trade and the more flexible the exchange rate is. Indeed, a recent formal analysis of the effects of trade openness on monetary policy transmission using the medium-scale, two-country new Keynesian DSGE model by Cwik et al. (2011) provided strong counterfactual simulations showing that monetary transmission is significantly affected by trade openness and that the effects of a monetary policy shock on prices tend to increase with openness. On the other hand, trade openness might make inflation less sensitive to the degree of utilization of domestic productive capacity, because economic agents can buy goods and services abroad. As a consequence, the aggregate supply curve may become more horizontal. In such circumstances, a change in aggregate demand caused by a monetary policy shock will have a smaller effect on prices (BIS, 2006, chapter IV; Borio and Filardo, 2007).

The increasing internationalization of economies across the world in recent decades has led to domestic economic conditions being strongly influenced by foreign factors. In such circumstances, the possible effects of economic openness on monetary policy have become an important issue. Therefore, this study analyses crosscountry differences in the effects of economic openness on the responsiveness of prices to a monetary policy shock.

For the reasons put forth above, this paper focuses on the following questions: Is the impact of trade openness, financial openness and the exchange rate regime on price responses to a monetary policy shock important? What are the other potential determinants of monetary policy effects? Do differences in the legal and financial structure also affect price responses to a monetary policy shock? In order to answer these questions, we adopt a two-stage approach whereby the first part employs a structural vector autoregression (SVAR) model for each country in the sample to quantify the monetary policy effects, while in the second part the variations in price responses are explained by means of a number of covariates. By including 46 countries at different stages of development, this study substantially increases the scope of the analysis in comparison to the previous literature.

The rest of the paper is structured as follows: Section 2 explains the methodological approach to assessing price responses to a monetary policy shock. Section 3 presents the results and discusses their main implications. Section 4 subjects the main findings to a series of robustness checks, and Section 5 concludes the paper.

\section{Methodological Approach}

Our methodological approach to exploring sources of cross-country variations in monetary policy effects on prices consists of two parts. The first part employs a SVAR model and uses individual country data to obtain price (impulse) responses to monetary shocks for each country, while the second part gathers these results and 
uses them as an input in a cross-country regression which tests the significance of various factors in explaining the monetary policy effects on prices. Our analysis is limited to those countries for which (quarterly) data is available for all the variables in the model for at least 50 continuous observations, which results in 46 countries overall.

The data vector we use in the SVAR model is $\{\mathrm{Y}, \mathrm{CPI}, \mathrm{M}, \mathrm{IR}, \mathrm{ER}, \mathrm{OIL}, \mathrm{FFR}\}$, while the data definitions and sources are provided in Table A1 in the Appendix. All the variables, with the exception of the interest rate, are transformed into logarithms and the same model is initially used for each country.

To obtain impulse responses, we use the model presented in Kim and Roubini (2000) and Elbourne and Haan (2006); hence the short-run (contemporaneous) identification scheme is given as:

$$
\left[\begin{array}{c}
e_{Y} \\
e_{C P I} \\
e_{M} \\
e_{I R} \\
e_{E R} \\
e_{O I L} \\
e_{F F R}
\end{array}\right]=\left[\begin{array}{ccccccc}
1 & 0 & 0 & 0 & 0 & a_{16} & 0 \\
a_{21} & 1 & 0 & 0 & 0 & a_{26} & 0 \\
a_{31} & a_{32} & 1 & a_{34} & 0 & 0 & 0 \\
0 & 0 & a_{43} & 1 & a_{45} & a_{46} & a_{47} \\
a_{51} & a_{52} & a_{53} & a_{54} & 1 & a_{56} & a_{57} \\
0 & 0 & 0 & 0 & 0 & 1 & 0 \\
0 & 0 & 0 & 0 & 0 & a_{76} & 1
\end{array}\right]\left[\begin{array}{c}
\varepsilon_{Y} \\
\varepsilon_{C P I} \\
\varepsilon_{M} \\
\varepsilon_{I R} \\
\varepsilon_{E R} \\
\varepsilon_{O I L} \\
\varepsilon_{F F R}
\end{array}\right]
$$

where $e_{Y}$ is an output shock, $e_{C P I}$ is a price level shock, $e_{M}$ is a money demand shock, $e_{i}$ is a domestic interest rate shock, $e_{E R}$ is an exchange rate shock, $e_{O I L}$ is an oil price shock and $e_{F F R}$ is a foreign interest rate (federal funds rate) shock.

The identification given in (1) suggests the following: Output is assumed to be contemporaneously affected only by the world price of oil, while prices are additionally affected by the current value of output. As for the monetary aggregates, it is output, prices and the domestic interest rate that have a contemporaneous influence on money. The domestic interest rate is affected by current values of money, the exchange rate, oil prices and the federal funds rate, while the exchange rate is assumed to be affected by all the variables in the model. Lastly, the world price of oil and the federal funds rate are assumed to be contemporaneously exogenous to all the variables in the domestic economy, while the federal funds rate is assumed to be endogenous only to the world oil price. With the identification scheme thus formulated, we are able to provide a realistic approximation of the structure of the economy, especially accounting for the fact that most of the countries in our sample are highly open and affected by foreign shocks.

The number of lags used in obtaining impulse responses is dictated by the Lagrange multiplier statistic, with a minimum of four lags. Since economic theory postulates that a short-run reaction of prices to a contractionary monetary policy shock should be negative, in cases where the results appear to be implausible the model is altered by: increasing the number of lags, adding a trend, using the German instead of the US interest rate for European countries or adding dummy variables that take account of a change in the exchange rate regime. 
Table 1 Alphabetical List of Countries, Periods and Average Impulse Response Estimates

\begin{tabular}{|c|c|c|c|c|c|c|c|c|}
\hline Country & Period & $\mathbf{Y}$ & Country & Period & $\mathbf{Y}$ & Country & Period & $\mathbf{Y}$ \\
\hline Australia & 75Q1-09Q3 & -0.132 & Hungary & 95Q1-09Q4 & -0.389 & Portugal & 79Q4-98Q4 & -0.620 \\
\hline Austria & 75Q1-97Q4 & 0.001 & India & 71Q1-92Q4 & 0.107 & Russia & 95Q2-09Q3 & -0.003 \\
\hline Belgium & 80Q1-98Q3 & -0.083 & Ireland & 82Q4-98Q4 & -0.051 & Senegal & 76Q1-03Q4 & 0.370 \\
\hline Bolivia & 95Q1-09Q3 & -0.087 & Italy & 80Q1-98Q4 & -0.054 & Singapore & 84Q3-09Q4 & -0.498 \\
\hline Brazil & 95Q1-09Q4 & -0.001 & Japan & 75Q1-09Q3 & -0.392 & Slovenia & 94Q1-06Q4 & -0.294 \\
\hline Canada & 75Q1-09Q3 & -0.109 & Jordan & 92Q3-09Q3 & -0.150 & South Africa & 75Q1-09Q4 & -0.002 \\
\hline Chile & 85Q1-09Q3 & -0.002 & S. Korea & 76Q4-08Q4 & -0.023 & Spain & 75Q1-98Q4 & -0.040 \\
\hline Colombia & 95Q1-09Q4 & 0.000 & Lithuania & 96Q4-09Q4 & -0.001 & Sweden & 75Q1-04Q3 & -0.009 \\
\hline Croatia & 94Q2-09Q2 & -0.050 & Mexico & 85Q4-09Q3 & -0.001 & Thailand & 97Q1-09Q4 & -0.188 \\
\hline Cyprus & 96Q1-07Q4 & -0.240 & Morocco & 94Q1-09Q1 & -0.094 & $\begin{array}{l}\text { Trinidad } \\
\text { and Tobago }\end{array}$ & 91Q1-08Q1 & 0.018 \\
\hline Czech Rep. & 94Q1-09Q4 & -0.033 & Netherlands & 81Q1-97Q4 & -0.223 & Tunisia & 93Q1-09Q4 & -0.463 \\
\hline Denmark & 91Q1-09Q4 & -0.048 & N. Zealand & 94Q1-09Q3 & -0.248 & Turkey & 87Q1-09Q4 & -0.002 \\
\hline Estonia & 93Q4-09Q3 & -0.164 & Norway & 79Q1-04Q3 & -0.018 & UK & 75Q1-09Q4 & -0.065 \\
\hline Finland & 78Q1-98Q4 & -0.169 & Peru & 91Q1-09Q2 & 0.000 & USA & 75Q1-09Q4 & -0.163 \\
\hline France & 77Q4-98Q4 & -0.020 & Philippines & 81Q1-06Q3 & -0.229 & & & \\
\hline Germany & 75Q1-98Q4 & -0.360 & Poland & 96Q4-09Q4 & -0.042 & & & \\
\hline
\end{tabular}

Note: "Y" refers to the average effect of monetary policy shock on prices over eight quarters.

Impulse response functions based on the model specified in (1) are used to create a measure of the short-run monetary policy effect on prices. Following previous studies of cross-sectional differences in monetary policy effects (Carlino and DeFina, 1998, 1999; Mihov, 2001; Elbourne and Haan, 2006), we construct this measure as an average price response to a monetary policy shock (a one percentage point increase in the interest rate) over the first eight quarters. The average is used rather than the maximum (negative) response to a monetary policy shock (as used in some studies; see, for example, Cecchetti, 1999; Elbourne and Haan 2006; Aysun et al., 2013) to reduce the possible effects of extreme point estimates on the results of our subsequent analysis of cross-section variations in monetary policy effects. ${ }^{1}$ We employ the time span of eight quarters because theoretical models (see, for example, Taylor and Wieland, 2012) usually imply monetary policy transmission lags of similar length. This period of eight quarters is also commonly assumed by policymakers as necessary for monetary policy changes to have their full impact on the economy (Bank of England, 1999; ECB, 2010). Table 1 reports these average responses for the countries included in our sample, as well as the time periods available for estimation.

The results from Table 1 are used in the second stage of our analysis as the dependent variable in the following model:

\footnotetext{
${ }^{1}$ Note also that the measure of the short-run monetary policy effect on prices expressed as an average is equivalent to a cumulative response to a monetary policy shock used in some studies. These two are equivalents because the average is obtained as a cumulative response divided by eight.
} 


$$
Y_{j}=I n t+\sum X_{j k} \alpha_{k}+u_{j}
$$

where $Y_{j}$ represents the estimated effect of a monetary policy shock; Int is the intercept term; $X_{j k}$ stands for explanatory variables; $\alpha_{k}$ are coefficients to be estimated; $u_{j}$ is the regression residual; $j=1, \ldots, n$ indexes countries; $k=1, \ldots, m$ indexes explanatory variables.

To empirically investigate the relationship between the international dimension of national economic activity and the effects of a monetary policy shock, the vector of explanatory variables includes indicators for trade openness, financial openness and the exchange rate regime. As before, the definitions and sources of these variables are given in Table Al in the Appendix. It should additionally be emphasized that the issue of identifying the exchange rate regime in a certain country is not straightforward. The difficulty stems from the existence of disparities between the officially reported exchange rate regime, which is compiled by the International Monetary Fund (IMF) (de jure classification), and the actual exchange rate regime that exists in a particular country. In the present paper this difficulty is circumvented by using exchange rate regime classification Ilzetzki et al. (2008), which distinguishes between 14 unified exchange rate systems. Specifically, Ilzetzki et al. (2008) assign number 1 to the least flexible exchange rate arrangements and number 14 to the most flexible. In this study, we undertake just one small adaptation of this classification and merge the last two (very similar) categories - the free-floating (number 13) and free-falling (number 14) - into a single category (to which we assign number 13). We then create a proxy for the exchange rate regime by taking the average value of the exchange rate category in a certain country over the considered sample periods.

Following previous empirical literature, we also consider whether price responsiveness to a monetary policy shock is systematically related to the size and development of the banking sector. Under the traditional interest rate channel of monetary policy, a change in the short-term interest rate induced by monetary policy measures leads to a change in various long-term interest rates. This change in longterm interest rates then affects economic agents' spending decisions depending on the use of credit in the economy. In consequence, the size and development of the banking sector can determine the short-run monetary policy effect on prices. To consider this relationship, the following variables are used: the ratio of deposit money bank assets to GDP, the ratio of private credit by deposit money banks to GDP, the ratio of bank deposits to GDP and the ratio of liquid liabilities to GDP. We use the data base of Beck et al. (2010) to construct the above-mentioned variables.

Cecchetti (1999) argues that countries' respective legal structures, financial structures and monetary transmission mechanisms are interconnected. Namely, the differences in financial structures across countries can be a consequence of their dissimilar legal structures. Countries with a legal structure based on English common law have, on average, better legal protection for shareholders and debtors and consequently more developed equity and bond markets. Under such a financial structure, the lending channel of monetary transmission is expected to be weaker and the effects of a monetary policy shock on the economy smaller. Therefore, we use the data on a country's legal origin from Djankov et al. (2007) and introduce dummies for English, French, German and Nordic legal origins separately into the regression. 
Finally, previous studies suggest that cross-country variations in output responses to a domestic monetary policy shock can be related to variations in the shares of interest-sensitive sectors (manufacturing) across countries. As argued by Carlino and DeFina (1999), these differences occur due to the fact that demand for durable and non-durable goods exhibits different interest rate sensitivities. Similarly, an industry's response to a domestic monetary policy shock may depend on whether it produces necessary or luxury goods. Although these considerations primarily reflect monetary policy effects on output, we still include the share of industry in GDP among the set of explanatory variables in order to control for the possibility that cross-country variations in price responses to a monetary policy shock can also be related to variations in economic structure. This variable is calculated from World Development Indicators (WDI) data on the shares of industry value added in a country's GDP.

The Appendix gives the definitions and sources of the variables used in the second part of our empirical investigation.

Unfortunately, the data on these variables are not available for all countryperiods included in our analysis. Therefore, we adopt two general principles in the construction of the data set. Where less than $20 \%$ of observations are missing, the average for the variable is still calculated. If more than $20 \%$ of observations are missing, we exclude the country from the investigation.

\section{Estimation Results}

Table 2 reports the results of our cross-country analysis. Before embarking on interpretation of the coefficients, it should be stressed that we include only one financial variable at a time, since variance inflation analysis displays evidence of substantial multicolinearity when all financial variables are included in the regression simultaneously.

The standard diagnostic tests reveal that the reported models are well specified with respect to multicolinearity, normality, heteroscedasticity and functional form. In particular, according to standard criteria, variance inflation analysis suggests that collinearity does not pose a problem, either for individual variables or the model as a whole. The reported results of the diagnostic tests reveal that the null hypothesis of normal skewness or kurtosis cannot be rejected at standard levels of statistical significance, suggesting that all models are well specified with respect to normality. Further tests (Cameron and Trivedi and Breusch-Pagan tests suggest that there is no problem with heteroskedasticity of residuals as the null of homoscedasticly distributed errors cannot be rejected at standard levels of statistical significance. The Ramsey RESET test is unable to reject the null of no omitted variables or correct functional form at conventional levels of significance. Finally, the outlier-robust estimations (available on request) show that the results reported in Table 2 are not influenced by undue "leverage" on the regressions exerted by observations with extreme values.

Since we adopt a two-step research strategy, in the second step we use the estimated rather than the observed values for the dependent variable. In cases such as this, variations in the error of the estimation of the dependent variable may induce heteroscedasticity in the second step of the analysis. As demonstrated in Lewis and 
Table 2 The Results of Cross-Country Regressions

\begin{tabular}{|c|c|c|c|c|}
\hline \multirow[t]{2}{*}{ Dependent variable } & \multicolumn{4}{|c|}{ Average effect on prices } \\
\hline & (1) & (2) & (3) & (4) \\
\hline Trade openness & $\begin{array}{l}-0.0013^{* * *} \\
(0.0005)\end{array}$ & $\begin{array}{l}-0.0013^{* * *} \\
(0.0005)\end{array}$ & $\begin{array}{l}-0.0013^{* *} \\
(0.0005)\end{array}$ & $\begin{array}{l}-0.0012^{* *} \\
(0.0006)\end{array}$ \\
\hline Financial openness & $\begin{array}{c}0.0081 \\
(0.0197)\end{array}$ & $\begin{array}{c}0.0094 \\
(0.0203)\end{array}$ & $\begin{array}{c}0.0052 \\
(0.0197)\end{array}$ & $\begin{array}{c}0.0027 \\
(0.0215)\end{array}$ \\
\hline Exchange rate & $\begin{array}{l}-0.0240^{* * *} \\
(0.0092)\end{array}$ & $\begin{array}{l}-0.0243^{* * *} \\
(0.0092)\end{array}$ & $\begin{array}{l}-0.0234^{* * *} \\
(0.0091)\end{array}$ & $\begin{array}{l}-0.0251^{* * *} \\
(0.0095)\end{array}$ \\
\hline Deposit money bank assets & $\begin{array}{l}-0.00166^{\star * *} \\
(0.0006)\end{array}$ & & & \\
\hline Private credit & & $\begin{array}{l}-0.0019^{* * *} \\
(0.0007)\end{array}$ & & \\
\hline Bank deposits & & & $\begin{array}{l}-0.0021^{* *} \\
(0.0010)\end{array}$ & \\
\hline Liquid liabilities & & & & $\begin{array}{l}-0.0020^{*} \\
(0.0012)\end{array}$ \\
\hline English legal origin & $\begin{array}{l}0.0919 * * \\
(0.0436)\end{array}$ & $\begin{array}{l}0.1052^{\star *} \\
(0.0461)\end{array}$ & $\begin{array}{l}0.1063^{\star *} \\
(0.0479)\end{array}$ & $\begin{array}{l}0.0986^{* *} \\
(0.0491)\end{array}$ \\
\hline Share of industry & $\begin{array}{c}0.0012 \\
(0.0045)\end{array}$ & $\begin{array}{c}0.0012 \\
(0.0045)\end{array}$ & $\begin{array}{c}0.0012 \\
(0.0043)\end{array}$ & $\begin{array}{c}0.0018 \\
(0.0048)\end{array}$ \\
\hline Constant & $\begin{array}{c}0.2073 \\
(0.1867)\end{array}$ & $\begin{array}{c}0.2052 \\
(0.1857)\end{array}$ & $\begin{array}{c}0.2029 \\
(0.1794)\end{array}$ & $\begin{array}{c}0.2055 \\
(0.2003)\end{array}$ \\
\hline No. of observations & 46 & 46 & 46 & 44 \\
\hline$R^{2}$ & 0.37 & 0.37 & 0.40 & 0.40 \\
\hline Wald Chi-square test & 0.02 & 0.02 & 0.03 & 0.07 \\
\hline \multicolumn{5}{|l|}{ Variance Inflation Factor } \\
\hline Maximum & 1.36 & 1.35 & 1.36 & 1.38 \\
\hline Mean & 1.24 & 1.27 & 1.23 & 1.23 \\
\hline \multicolumn{5}{|l|}{ Cameron \&Trivedi test for } \\
\hline Heteroscedasticity & 0.90 & 0.84 & 0.76 & 0.80 \\
\hline Skewness & 0.71 & 0.77 & 0.35 & 0.21 \\
\hline Kurtosis & 0.24 & 0.24 & 0.20 & 0.21 \\
\hline $\begin{array}{l}\text { Breusch-Pagan test } \\
\text { for heteroskedasticity }\end{array}$ & 0.65 & 0.80 & 0.84 & 0.82 \\
\hline Ramsey RESET test & 0.53 & 0.42 & 0.52 & 0.61 \\
\hline
\end{tabular}

Note: Numbers in parentheses are bootstrapped standard errors, while *,** and *** indicate the $10 \%, 5 \%$ and $1 \%$ levels of significance, respectively.

Linzer (2005), the use of the Monte Carlo simulations bootstrapping procedure in these circumstances resolves this problem by producing conservative but efficient standard errors. In consequence, we decide to report bootstrapped standard errors in our results for each model.

Since our dependent variable measures price responses to a monetary policy shock (expressed as a one percentage point increase in the interest rate), we expect these responses to be negative. This would suggest that a particular country characteristic, as measured by that variable, is on average related to a larger (negative) short-run effect of monetary policy on prices. On the other hand, a positive coef- 
ficient would be taken as an indication that the country characteristic is, on average, related to a smaller (negative) short-run effect of monetary policy on prices.

The results for our baseline specifications (models) are reported in Table 2. All the models are significant at the conventional levels of statistical significance and the reported regressions explain $37 \%$ to $40 \%$ of cross-country variations in the average price responses to a monetary policy shock.

The results in Table 2 point towards the importance of the international dimension of economic activity for the short-run effects of monetary policy on domestic prices.

In particular, the coefficients on trade openness are negative and statistically significant in all the models. This suggests that in countries with higher trade openness (a larger share of international trade in GDP) a monetary policy shock has, on average, a larger effect on prices. These results support the results of the new Keynesian DSGE model of Cwik et al. (2011), which suggests that the effects of a monetary policy shock on prices tend to increase with openness. They are also consistent with the traditional monetarist hypothesis that the exchange rate channel is an important channel in monetary transmission.

The results in Table 2 indicate that the coefficient on the exchange rate regime is also negative and statistically significant in all the specifications. Given the construction of our measure of the exchange rate (the least flexible exchange rate arrangements are assigned the lowest values), the negative coefficient suggests that in countries with more flexible exchange rates a monetary policy shock has, on average, a larger short-run effect on prices. These results are in line with the typical standpoint that monetary policy can affect the short-run domestic economic conditions more if a country has a flexible exchange rate.

In contrast to the trade openness and exchange rate variables, the coefficient on the financial openness variable appears not to be statistically significant in any specification. This result does not support the hypothesis that the growing internationalization of financial markets around the world undermines the ability of national central banks to affect prices. The positive but insignificant coefficients on financial openness support the results of Woodford's (2010) model, which suggests that financial openness does not substantially reduce the short-run effects of monetary policy on prices.

All financial variables in our specifications are found to have a negative and statistically significant impact. This finding suggests that a monetary policy shock has, on average, a larger short-run effect on prices in countries with a larger and more developed banking sector. These findings correspond to those of Cecchetti's (1999), Mihov's (2001) and Matějü's (2013) empirical studies of cross-country differences in the effects of monetary policy shocks, providing further evidence supporting the importance of the financial sector in monetary policy transmission.

The results also indicate that the dummy variable for English legal origin is positive in all specifications and statistically significant at conventional levels. These results support Cecchetti's (1999) findings and suggest that in countries with English legal origin a monetary policy shock has, on average, a smaller effect on prices. Finally, the coefficients on the industry variable appear not to be statistically significant. 
To sum up, our results indicate that a country's trade openness, exchange rate regime, level of development of the banking sector and legal origin are important determinants of the size of monetary policy effects on prices. The results show that the response of prices to a monetary policy shock is significantly larger in countries with higher trade openness, a more flexible exchange rate and a larger and more developed banking sector, while price responsiveness is smaller in countries with English legal origin. Furthermore, taken together, the results on trade and financial openness do not provide empirical evidence to support the hypothesis ("fears" of some economists and policymakers) that the growing internationalization of economic activity undermines the ability of national central banks to affect prices.

\section{Robustness Checks}

We next set out to investigate whether there are other factors that significantly determine price responsiveness to a monetary policy shock which were not considered in our research, or whose introduction into the model would substantially change the results reported above. These new results are not reported but are available upon request.

First, we subject the dependent variable to robustness checks. Specifically, the use of the dependent variable created as an average response to a monetary policy shock over the first eight quarters was based on the standard implications of theoretical models about the length of monetary policy transmission lags. However, given that it was recently argued that these lags are longer on average (see, for example, Havranek and Rusnak, 2013), in checking the robustness of our results we create an alternative dependent variable as the average response to a monetary policy shock over the first 16 quarters. The estimated coefficients show that our main findings are robust to the use of the dependent variable constructed using a longer time span. The coefficients on financial variables, trade openness and the exchange rate remain negative and are almost always statistically significant.

Furthermore, we test whether using the largest point of magnitude as a measure of monetary policy effects has any influence on our conclusions. As explained earlier, the average response to a monetary policy shock was used in our benchmark models to reduce the possible effects of extreme value estimates on the results. We now construct the dependent variable as the maximum (negative) response to a monetary policy shock. The outlier-robust estimations indicate that when extreme value estimates of maximum (negative) responses to a monetary policy shock are taken into account, the results are very similar to the results reported in Table 2. In particular, the coefficients on financial variables and trade openness are always negative and statistically significant. All coefficients on the exchange rate are negative, but they lose their statistical significance.

We also control for various unobserved characteristics which might influence monetary policy transmission.

In particular, given the heterogeneity of the countries in our sample, we test the link between the variations in economic size and development level and crosscountry variations in the responses of prices to a monetary policy shock. We calculate these as the ratio of a country's real GDP to the world real GDP and the ratio of a country's real GDP per capita to the world real GDP per capita. 
The estimated results indicate that the effects of a monetary policy shock are not affected by country variations in economic size or development. In addition, the dummy variables for the low-middle, upper-middle and high income groups of countries are introduced in the model. The introduced dummy variables appear not to be significant, suggesting that the effects of monetary policy on prices do not differ among these income groups. We also introduce dummies for Anglo-Saxon countries, South American countries, European countries, Far East countries, Scandinavian countries and Eastern European countries. Once again, no significantly different monetary policy effects in any of these groups of countries were found.

We next investigate whether different structures of aggregate demand across countries (as a consequence of possible differences in interest rate elasticity) are systematically linked to variations in the effects of monetary policy. To this end, we employ the shares of aggregate consumption, investment and government consumption in GDP. Our results reveal that the shares of different aggregate demand components and monetary policy effects are significantly related.

We also test the robustness of our findings to the use of alternative measures of the exchange rate regime. In particular, the exchange rate regime measure is constructed analogously to the one employed in Table 2, but this time we use "coarse" classification of Ilzetzki et al. (2008) instead of the "fine" classification. Using each of these classifications, we also construct new measures of the exchange rate regime (i.e. without merging the free-floating and the free-falling regimes into a single category as we did before). The obtained estimates do not reveal any notable difference regarding the above-reported (Table 2) results on financial openness and the exchange rate regime.

\section{Conclusion}

What determines the size of monetary policy effects on prices? Our results suggest that these effects are, on average, larger in countries with higher openness to international trade. Hence, our empirical findings support the results of the recent theoretical analysis carried out by Cwik et al. (2011), which suggests that the effects of a monetary policy shock on prices should be larger when a country is more involved in international trade.

Furthermore, our results suggest that the size of monetary policy effects on prices is larger on average in countries with more flexible exchange rates, confirming the standard stance that monetary policy is more able to affect short-run domestic economic conditions when a country has a flexible exchange rate.

With respect to financial openness, our study does not find any significant effect of the size of financial openness on the responsiveness of prices to a monetary policy shock. Thus, our results on financial openness support Woodford's (2010) theoretical analysis, which suggests that an increase in international capital flows should not substantially reduce the short-run effects of monetary policy on prices.

Finally, with respect to the previous empirical studies of cross-country differences in the effects of monetary policy shocks, our results support findings of Cecchetti (1999), Mihov (2001) and Aysun et al. (2013), stressing the importance of the financial structure in monetary policy transmission. More precisely, our results suggest that a monetary policy shock has, on average, a larger effect on prices in 
countries with a larger and more developed banking sector. The results also indicate that a monetary policy shock has, on average, a smaller effect on prices in countries with a legal structure based on English common law which have more developed equity and bond markets.

\section{APPENDIX}

\section{Table A1 Definitions and Sources of the Variables Included in the SVAR Model and Cross-Country Analysis}

\begin{tabular}{|c|c|c|}
\hline Variable & Indicator & Source \\
\hline $\mathrm{Y}$ & $\begin{array}{l}\text { Index of GDP volume or index } \\
\text { of industrial production* }\end{array}$ & $\begin{array}{l}\text { International Financial } \\
\text { Statistics }\end{array}$ \\
\hline $\mathrm{CPI}$ & Consumer price index or GDP deflator* & $\begin{array}{l}\text { International Financial } \\
\text { Statistics }\end{array}$ \\
\hline M & Monetary aggregate $\mathrm{M} 1$ or $\mathrm{M} 2$ or $\mathrm{M}^{*}$ & $\begin{array}{l}\text { International Financial } \\
\text { Statistics }\end{array}$ \\
\hline IR & Money market rate or deposit rate* & $\begin{array}{l}\text { International Financial } \\
\text { Statistics }\end{array}$ \\
\hline ER & $\begin{array}{l}\text { Nominal effective exchange rate index } \\
\text { or the official US dollar exchange rate* }\end{array}$ & $\begin{array}{l}\text { International Financial } \\
\text { Statistics }\end{array}$ \\
\hline OIL & Petroleum prices in US dollars per barrel & $\begin{array}{c}\text { International Financial } \\
\text { Statistics }\end{array}$ \\
\hline FFR & US federal funds rate & $\begin{array}{l}\text { International Financial } \\
\text { Statistics }\end{array}$ \\
\hline $\begin{array}{l}\text { Deposit money } \\
\text { bank assets }\end{array}$ & $\begin{array}{c}\text { Average value of the ratio of deposit money } \\
\text { bank assets to GDP over the considered } \\
\text { sample periods }\end{array}$ & Beck et al. (2010) \\
\hline Private credit & $\begin{array}{c}\text { Average value of the private credit by deposit } \\
\text { money banks to GDP over the considered } \\
\text { sample periods }\end{array}$ & Beck et al. (2010) \\
\hline Bank deposits & $\begin{array}{c}\text { Average value of the Bank deposits to GDP } \\
\text { over the considered sample periods }\end{array}$ & Beck et al. (2010) \\
\hline Liquid liabilities & $\begin{array}{l}\text { Average value of the Liquid liabilities to GDP } \\
\text { over the considered sample periods }\end{array}$ & Beck et al. (2010) \\
\hline Exchange rate & $\begin{array}{l}\text { Average value of the exchange rate } \\
\text { categories over the considered sample } \\
\text { periods }\end{array}$ & Ilzetzki et al. (2008) \\
\hline Trade openness & $\begin{array}{c}\text { Average value of the sum of imports and } \\
\text { exports to GDP over the considered sample } \\
\text { periods }\end{array}$ & Penn World Table 7.0 \\
\hline Financial openness & $\begin{array}{l}\text { Average value of the measure of financial } \\
\text { openness over the considered sample } \\
\text { periods }\end{array}$ & Chinn and Ito (2006) \\
\hline Share of industry & $\begin{array}{l}\text { Average value of the share of industry value } \\
\text { added in a country's GDP } \\
\text { over the considered sample periods }\end{array}$ & $\begin{array}{l}\text { World Development } \\
\text { Indicators }\end{array}$ \\
\hline English legal origin & $\begin{array}{l}\text { Dummy variable taking the value of } 1 \\
\text { for English legal origin, and } 0 \text { otherwise }\end{array}$ & Djankov et al. (2007) \\
\hline
\end{tabular}

Notes: * depending on the data availability. All indices are based on 2005 data. 


\section{REFERENCES}

Aysun U, Brady R, Honig A (2013): Financial frictions and the strength of monetary transmission. Journal of International Money and Finance, 32:1097-1119.

Bank for International Settlements (BIS) (2006): $76^{\text {th }}$ Annual Report. Basel.

Bank of England (1999): The Transmission Mechanism of Monetary Policy. Bank of England Monetary Policy Committee, London.

Beck T, Demirgüç-Kunt A, Levine R (2010): Financial institutions and markets across countries and over time: the updated financial development and structure database. World Bank Economic Review, 24:77-92.

Bernanke BS (2007): Globalization and Monetary Policy. Speech at the Fourth Economic Summit, Stanford Institute for Economic Policy Research, Stanford.

Borio C, Filardo A (2007): Globalization and inflation: New cross-country evidence on the global determinants of domestic inflation. BIS Paper, no. 227.

Carlino GA, DeFina R (1998): The differential regional effects of monetary policy. Review of Economics and Statistics, 80:572-587.

Carlino GA, DeFina R (1999): The differential regional effects of monetary policy: evidence from the U.S. states. Journal of Regional Science, 39:339-358.

Cecchetti SG (1999): Legal structure, financial structure, and monetary policy transmission mechanism. FRB of New York, Economic Policy Review, July:9-28.

Chinn MD, Ito H (2006): What matters for financial development? Capital controls, institutions, and interactions. Journal of Development Economics, 81:163-192.

Ćorić B, Malešević Perović L, Šimić V (2014): Openness and the Strength of Monetary Transmission: International Evidence. SSRN Working Paper, http://dx.doi.org/10.2139/ssrn.1997184.

Cwik T, Müller GJ, Wolters MH (2011): Does trade integration alter monetary policy transmission? Journal of Economic Dynamics and Control, 35:545-564.

Djankov S, McLiesh C, Shleifer A (2007): Private credit in 129 countries. Journal of Financial Economics, 84:299-329.

Elbourne A, Haan J de (2006): Financial structure and monetary policy transmission in transition countries. Journal of Comparative Economics, 34:1-23.

European Central Bank (ECB) (2010): Monthly Bulletin: May. Frankfurt.

Gudmundsson M (2008): Financial globalisation: key trends and implications for the transmission mechanism of monetary policy. BIS Paper, no. 39 .

Havranek T, Rusnak M (2013): Transmission Lags of Monetary Policy: A Meta-Analysis. International Journal of Central Banking, 9:39-75.

Ilzetzki EO, Reinhart CM, Rogoff K (2008): Exchange Rate Arrangements into the $21^{\text {st }}$ Century: Will the Anchor Currency Hold? Cambridge, Harvard University.

Kamin SB (2010): Financial globalization and monetary policy. Washington, Board of Governors of the Federal Reserve System.

Kim S, Roubini N (2000): Exchange rate anomalies in the industrial countries: a solution with a structural VAR approach. Journal Monetary Economics, 45:561-586.

Lewis JB, Linzer DA (2005): Estimating regression models in which the dependent variable is based on estimates. Political Analysis, 13:345-364.

Matějů J (2013): Explaining the Strength and the Efficiency of Monetary Policy Transmission: A Panel of Impulse Responses from a Time-Varying Parameter Model. Charles University in Prague, Faculty of Social Sciences, IES Working Paper, no. 18.

Meier S (2013): Financial Globalization and Monetary Transmission. FRB of Dallas Globalization and Monetary Policy Institute, Paper, no. 145. 
Meltzer AH (1995): Monetary, Credit and (Other) Transmission Processes: A Monetarist Perspective. Journal of Economic Perspectives, 9:49-72.

Mihov I (2001): Monetary policy implementation and transmission in the European monetary union. Economic Policy, 16:371-406.

Mishkin FS (1995): Symposium on the Monetary Transmission Mechanism. Journal of Economic Perspectives, 9:3-10.

Mishkin FS (2009): Globalization, Macroeconomic Performance, and Monetary Policy. Journal of Money, Credit and Banking, 41:187-196.

Owyang MT, Wall HJ (2009): Regional VARs and the channels of monetary policy. Applied Economics Letters, 16:1191-1194.

Rogoff KS (2003): Globalization and Global Disinflation. FRB of Kansas City Economic Review, Fourth quarter:45-78.

Rogoff KS (2007): Impact of globalization on monetary policy. In: The New Economic Geography: Effects and Policy Implications. FRB of Kansas City, pp. 265-305.

Rusnak M, Havranek T, Horvath R (2013): How to Solve the Price Puzzle? A Meta-Analysis. Journal of Money, Credit and Banking, 45:37-70.

Taylor JB, Wieland V (2012): Surprising Comparative Properties of Monetary Models: Results from a New Model Database. Review of Economics and Statistics, 94:800-816.

Woodford M (2010): Globalization and monetary control. In: Gali J, Gertler M (Eds): International Dimension of Monetary Policy. University of Chicago Press, pp. 13-77.

Yellen JL (2006): Monetary Policy in a Global Environment. Speech at the Euro and the Dollar in a Globalized Economy Conference. U.C. Santa Cruz. 